\title{
Determination of Aquifer Position Using Electric Geophysical Method
}

\author{
V. I. Obianwu ${ }^{1}$, O. E. $\operatorname{Atan}^{2} \&$ A. A. Okiwelu ${ }^{1}$ \\ ${ }^{1}$ Department of Physics (Geophysics Unit), University of Calabar, P.M.B. 1115, Calabar, Nigeria \\ ${ }^{2}$ Department of Physics, Cross River University of Technology, Calabar, Nigeria \\ Correspondence: V. I. Obianwu, Department of Physics (Geophysics Unit), University of Calabar, P.M.B. 1115, \\ Calabar, Nigeria. Tel: 234-803-347-3805. E-mail: vimobianwu@unical.edu.ng, vimoseis@yahoo.co.uk
}

Received: October 29, 2014 Accepted: November 23, 2014 Online Published: March 17, 2015

doi:10.5539/apr.v7n2p83 URL: http://dx.doi.org/10.5539/apr.v7n2p83

\begin{abstract}
Aquifer positions were determined by using Schlumberger electrode configuration to conduct Vertical Electrical Soundings in 67 communities within the study area. This study was carried out because of the presence of failed boreholes and manually dug wells in some of the Local Government Areas in the study area. More précis information relating to the exact location of aquifers is therefore needed for successful management of water resources in the area, in the face of dwindling availability of portable water, occasioned by failed boreholes and the need to carter for the increasing population of inhabitants of the area. Interpretation of data showed two to six geoelectric layers. Reflection coefficient and resistivity contrast values greater than 0.9 and 19 respectively, were obtained in some VES stations. Productive shallow and deep aquifer terrains were identified with depth of $60 \mathrm{~m}$ and $150 \mathrm{~m}$ respectively and resistivity range of 100.0-500.0 $\Omega \mathrm{m}$ for shallow aquifers and 1000-2500 $\Omega \mathrm{m}$ for deep aquifers, respectively. The lithologic materials for the aquifers were sand/sandstone and very coarsed grained sand/fractured basement, respectively. The above inference on lithology was constrained by borehole logs in the study area.
\end{abstract}

Keywords: vertical electrical sounding, groundwater, electrical resistivity, aquifer, electrode separation

\section{Introduction}

The central parts of Cross River State, Nigeria, forms part of the geopolitical and geographic entity where the Cross River State Government has dissipated so much energy to upgrade its natural and human resources. Since the commencement of the democratic experiment in 1999, the Cross River State Government has initiated policies like the Urban Renewal Scheme, which led to the improvement of facilities in some urban centres in the state and a corresponding population growth within those urban centres, which include Yakurr and Ikom Local Government Areas, which are part of the study area. In another policy of the state government tagged: "Rural Development Policy", the emphasis on development was shifted to the rural communities which constituted the bulk of the state population. These two policies have resulted in population increases within the urban centres and the rural areas.

These population increases has put so much pressure on the available water supply. The situation is further worsened by the fact that the water boards have become moribund and the pressure on available water facilities has led to the overstretching of these facilities where they exist at all, hence the development and expansion of water facilities to meet present and future demands of the communities in the study area have become very expedient. Although for over a decade, there had been some effort to develop and expand these facilities, especially in the area of exploitation of ground water, however most of these boreholes have since stopped producing. The effort made by government is evident by the presence of failed boreholes and manually dug wells in some of the Local Government Areas in the study area.

The consequences of having failed wells have been so grievous to the extent that a greater part of the population seem to depend on surface water sources like rivers and streams whose availability and safety cannot be guaranteed as these surface water sources are both seasonal and prone to contamination. This clearly manifest in the outbreak of some water born diseases like guinea worm, bilharziasis, typhoid, and cholera during the dry season when most wells must have dried up, leaving the people with only surface water to contend with. In the light of the foregoing, it is essential to have a geophysical and hydrogeological database that will help in groundwater development in the study area, hence the need for this study. 
It is known that successful exploration, exploitation and management of groundwater require a good knowledge of the spatial distribution of aquifer hydraulic parameters such as lithology, thickness, usable capacity and other hydraulic properties (George et al., 2011). Where such information are not available geophysical surveys should be performed (George et al., 2011). Geophysical investigations like the electrical resistivity method and seismic refraction method are good tools for site investigation towards the determination of overburden thickness, bed rock competence and mapping of subsurface structures before excavation and construction (Kurthenecker, 1934; Drake, 1962; Early \& Dyer, 1964; Burton, 1976; Nun, 1979; Kearey \& Brooks, 1984; Olorunfemi \& Meshida, 1987). Geophysicists, geologists and engineers use these two methods quite often in foundation and groundwater investigations. Both methods can be used in geotechnics to assess the rock strength, determine rippability and potential fluid content (Ayolabi, 2004; Ayolabi et al., 2008). One of the methods of evaluating aquifer characteristics is the pumping tests, which is time consuming and expensive, however results from Shingal and Niwas (1985) and Ahmed et al. (1988) indicate that the DC resistivity method does provide a fast, economic and nondestructive way to study aquifers (Young \& Lee, 2000).

Electrical resistivity is also widely considered as a useful parameter for hydrogeological studies, because the value is mainly controlled by lithological conditions of the aquifer (George et al., 2011). Additionally, it can be useful in the correlation of lithological facies between wells (Bell, 1993; El Gamili et al., 2001). However, resistivity values are also sensitive to the porosity and water content of the aquifer as well as to the mineralization and salinity of groundwater (McNeil, 1980; Parasins, 1997; Posdyakova et al., 2001; Choudhury \& Saha, 2004), as such, for an effective use of geoelectrical resistivity data for hydrogeologic study, the data from lithology logs should be used to constrain the field data (George et al., 2011), which is what is applicable in this work. The electrical resistivity method was deployed in this work to determine the ground water potentials of rocks within the study area.

\section{Geology and Hydrogeology of the Study Area}

The central part of Cross River State where this research is carried out lies between latitude $5^{\circ} 45^{\prime} \mathrm{N}$ and $6^{\circ} 28^{\prime} \mathrm{N}$ of the equator and between longitude $8^{\circ} 00^{\prime} \mathrm{E}$ and $9^{\circ} 11^{\prime} \mathrm{E}$ of the Greenwich meridian. The area includes the Ikom-Mamfe embayment and Boki Geological environment. The Ikom-Mamfe embayment is the Northwest to Southeast segment of the Northeast to Southwest trending Benue Trough. It extends laterally into parts of Western Cameroon, where it covers an area of $2,016 \mathrm{~km}^{2}$ (Eseme et al., 2002). It occupies the low lying areas between the Oban Massif and the Obudu plateau in Cross River State, Nigeria and is characterized by low relief and gently undulating topography (Eseme et al., 2002) (see Figure 1). This basin covers some of the communities in Abi, Yakurr, Obubra, Ikom and Etung Local Government Areas, which constitute part of the study area.

The Precambrian basement rocks under the Ikom-Mamfe basin is overlain by three major cretaceous lithostratigraphic units compromising the Asu River Group (ARG), Eze Aku Group (EAG) and the Post-Semtonian Nkporo-Afikpo shales formation (NASF) (see Figure 2). Some isolated incidences of alluvial deposits can also be found along parts of Cross River plains, while tertiary volcanic rocks like Basalts and dolerites intrude into the overlying cretaceous sedimentary units in some locations (Benkelil et al., 1975; Offodile, 1975; Cross River State Basin Development Authority (CRBDA), 1982; Nigerian Geological Survey Agency (NGSA), 2006) (see Figures $1-3$ ).

Migmatitic granitic gneisses, schists and pegmatite are the crystalline basement rocks which are prevalent in the basin. The gneiss are usually foliated with some pink feldspars and vary from fine homeblende, black to white with porhyroblastic feldspars. The albian ARG is the oldest sedimentary rocks in the study area and they directly overlie the Precambrian basement; They are basically non-marine to marginal marine in character and predominantly cover the eastern part of the study area. The sediments within the ARG consist of impervious shales, limestone with some sandstone intercalation and ammonites (NGSA, 2006; Odigi \& Amajor, 2009). The EAG comprises of thick flaggy impervious calcareous and non-calcareous shales, sandy shally limestone and calcareous sandstone (NGSA, 2006; Odigi \& Amajor, 2009). The EAG is overlain by the post santonian NASF which occupy most of the western parts of the study area. Sandstone, mudstone and shale are the major lithologic units in the formation (NGSA, 2006; Odigi \& Amajor, 2009). The shales are often carbonaceous and pyritic which is suggestive of sediments that were deposited in a poorly oxygenated shallow water environment with restricted air circulation (Peters et al., 1987).

The Cross River Basin Development Authority (CRBDA), in 1982 did a geological segmentation and on this basis Peters (1989) identified four shallow hydrogeological provinces consisting of the crystalline basement province (CBP), Cross River Plain Province (CRPP), Nkporo-Afikpo Shales Province (NASP) and 
Alluvial/Buried River Province (ABRP). The area exhibits a dendritic drainage pattern which is drained by the Cross River and some of its tributaries including Ovarr, Okwo, Lokpoi, Okang, Udip, Ujidam, Okpon, Atimaka, Aboine, Otere, Usee and Nde River (See Figure 3).

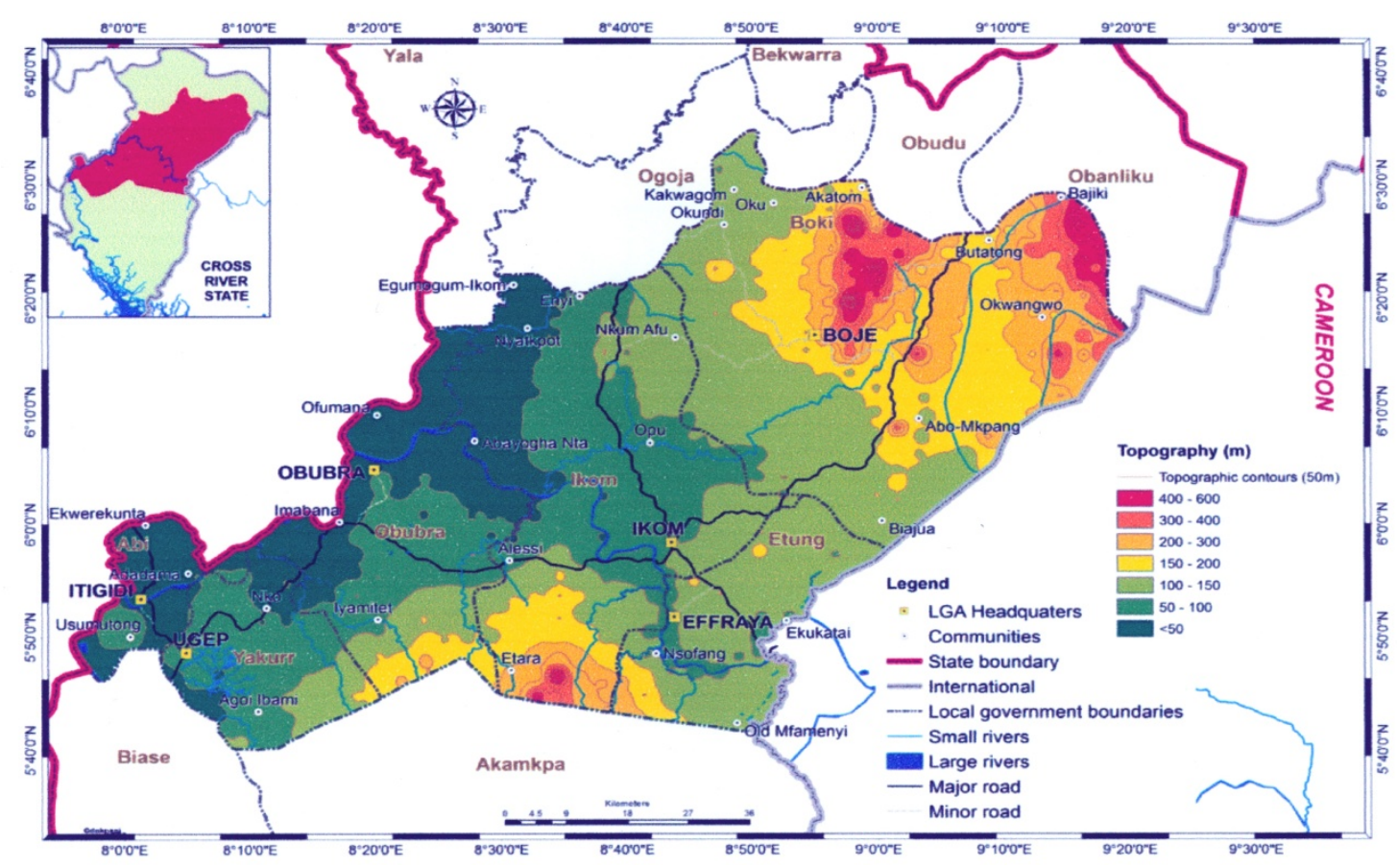

Figure 1. Topographic Map of Central Cross River State showing the Elevation

(Source: NGSA, 2006).

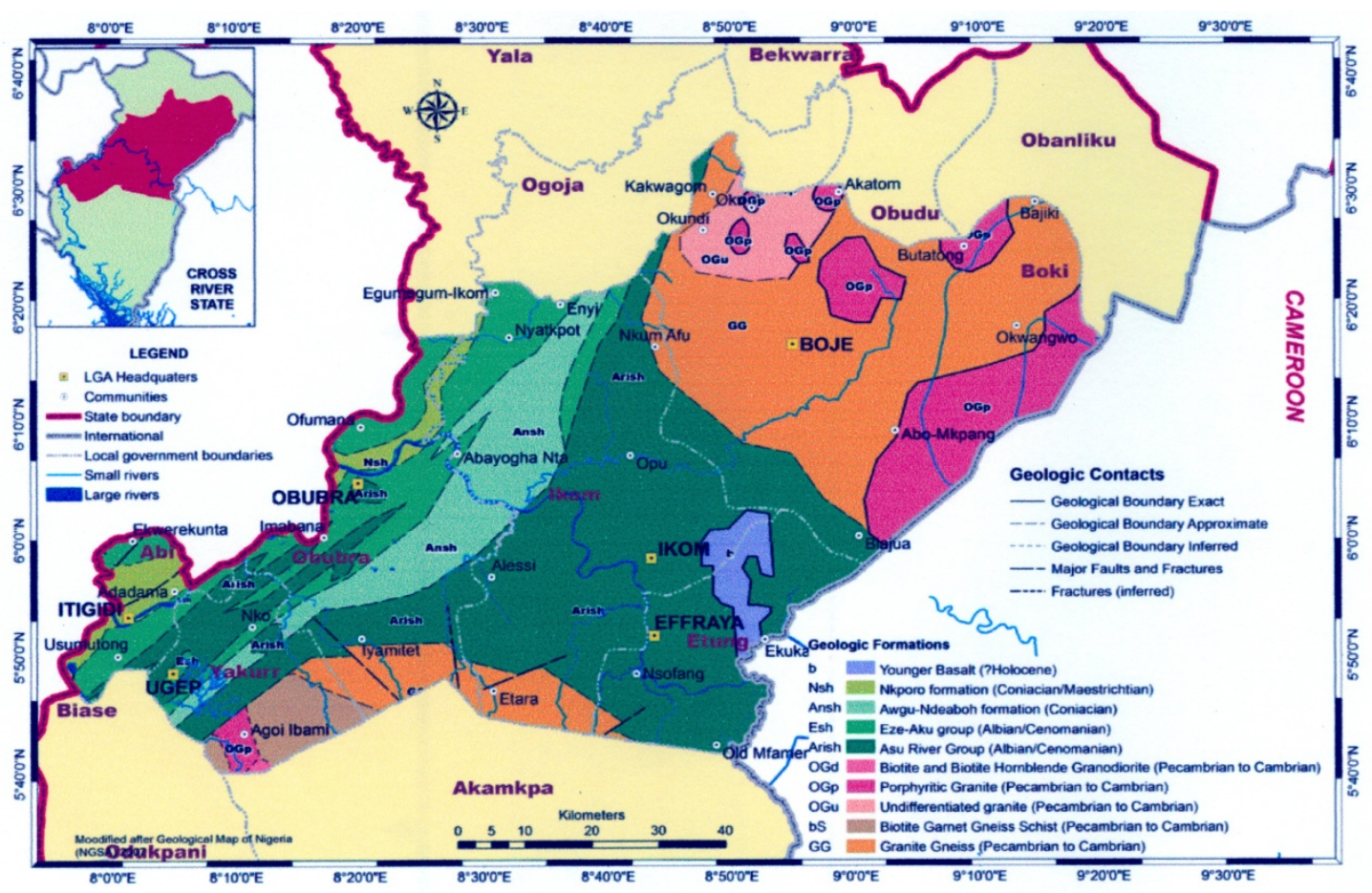

Figure 2. Location and geological map of the study area

(Source: NGSA, 2006). 


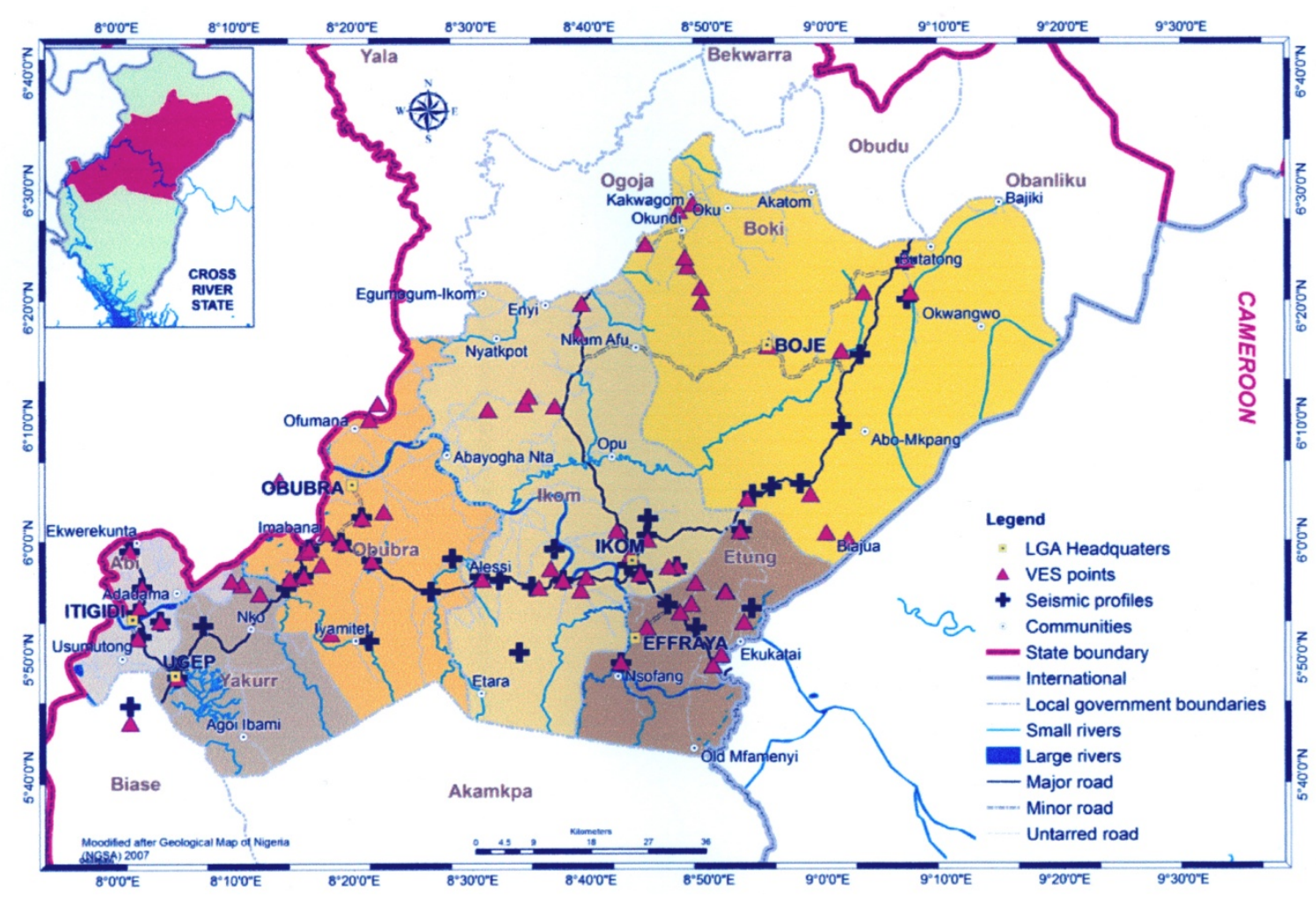

Figure 3. Map of the study area showing the Seismic Stations and VES points

(Source: NGSA, 2006).

Basalts and dolerites which are the major rock types in the CBP are distributed in patches in many parts of the study area, although the southern part of the study area is dominated by gneissic materials which is another major rock type in the CBP region. The occurrence of groundwater in the CBP is facilitated by the presence of secondary structures like fracture, faults, joints, fissures and other weathered litho-units. Ground water yield from these structures can occur even at depths as low as $50 \mathrm{~m}$ and may be poor in yield in some locations (Edet et al., 2011; Akpan et al., 2013). The single largest hydrogeological province is the CRPP, it covers the northern, central, southwestern and Northwestern parts of the study area. The aquiferous units in this province consists of deformed shales, siltstones, limestones and sandstones of Markurdi formation (Petters, 1989).

The NASP occupied the western part of the study area and consists basically of porous sandstones, compacted shales, mudstones, marls and clays (Petters, 1989; NGSA, 2006). The permeable sandstone appear to be an eastward extension of the adjoining Afikpo sandstones (Petters, 1989; Odoh, 2010). Most of the litho-units are porous and thus will have high yielding aquifers (Akpan, 2013).

\section{Materials and Method}

\subsection{Materials for Resistivity Survey}

Geoelectric sounding (VES) surveys in the study area were conducted using IGIS Resistivity meter model SSP-MP-ATS-MRP, with its accessories. Calibrated twine, hammer for driving down the steel electrodes and walkie-talkie were some of the additional materials used to facilitate the survey.

\subsection{Methods of Data Collection}

Conventional Schlumberger array VES (Telford et al., 1990) method was used to survey 67 sites with the electrode spacing $(\mathrm{AB})$ being extended to a maximum of $800 \mathrm{~m}$ in some of the sites. The measurement started with the choice of a centre of the electrodes spread at points that enable electrodes to be deployed along an approximately straight road. At each centre, traverse was established by separating two calibrated rolls of twine along two opposite directions. This usually gave a total traverse length of $450 \mathrm{~m}$ (that is $225 \mathrm{~m}$ either way). An extension of the line beyond this $450 \mathrm{~m}$ was made possible by the use of another roll of calibrated twine to obtain a traverse length of $500 \mathrm{~m}$. Measurement of the earth resistance R, commenced with the two potential electrodes $\left(\mathrm{P}_{1}\right.$ and $\left.\mathrm{P}_{2}\right)$ planted at $0.25 \mathrm{~m}$ respectively from the sounding centre giving an initial separation, $a$ of $0.5 \mathrm{~m}$ 
between them. The two current electrodes $\left(\mathrm{C}_{1}\right.$ and $\left.\mathrm{C}_{2}\right)$ were correspondingly given an initial separation $b$ of $2 \mathrm{~m}$, with each of them being situated a distance, equal to $1 \mathrm{~m}$ from the centre. These electrodes were connected to their respective terminals of the IGIS resistivity meter.

The Schlumberger array was employed with the maximum half current electrodes separation $(A B / 2)$ of $400 \mathrm{~m}$, which was deemed sufficient in allowing depth of penetration of the order of $133 \mathrm{~m}$ to $150 \mathrm{~m}$. The depth of current penetration using Schlumberger electrode array is $1 / 3$ to $1 / 4$ of AB/2 (Bernard, 2003; Roy and Apparao, 1971).

At some measurement points where the immediate Earth was hard and dry, the ground at such points was watered. After selecting four measurement cycles, the Earth resistance was automatically measured by activating the measure button on the instrument panel while "ON" in the "resistivity" mode.

At very large current electrode spread (that is for $b$ greater than $150 \mathrm{~m}$ ), it was necessary to use walkie-talkie to establish communication link with crew members at their various locations so that the extent of spread at any given measurement could be properly ascertained and relevant messages conveyed in the process. Some soundings were carried out near the sites of existing boreholes for comparative purposes (see Figure 4). The lithostratigraphic data of the boreholes used in constraining the inferences made in this study is shown in Figure 5.

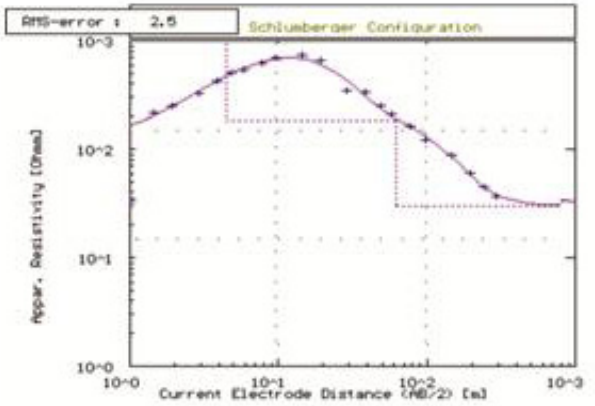

(a)
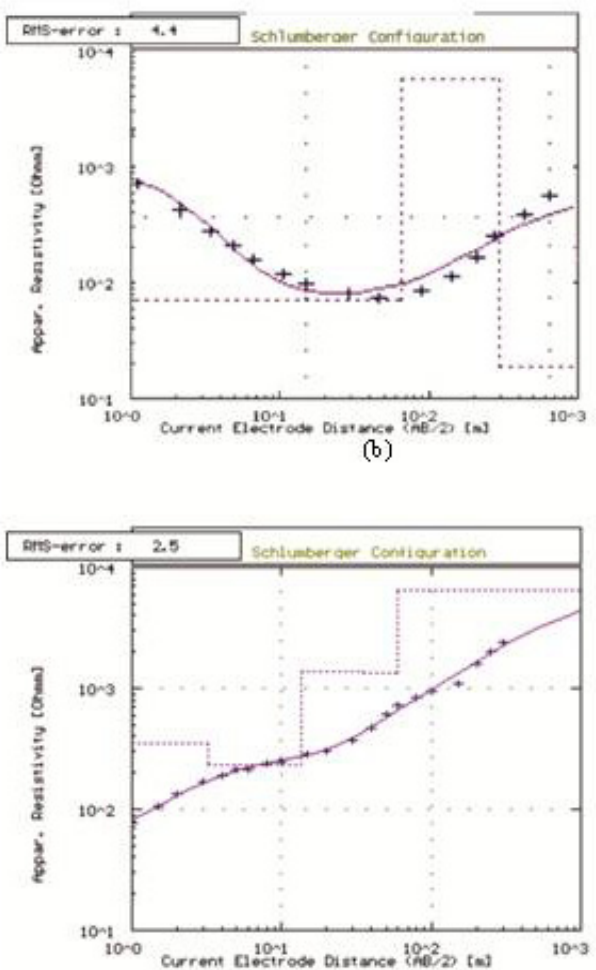

(c)
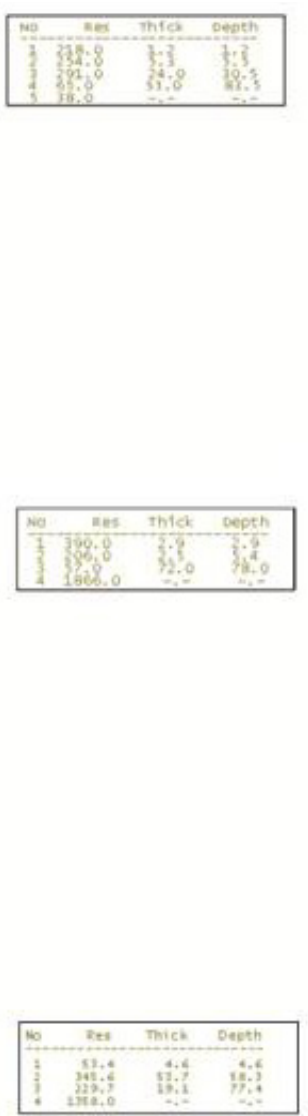

Figure 4. Apparent Resistivity model curves in the study area. Curve (a): apparent resistivity curve at Edondon; curve (b): apparent resistivity curve at Govisco; curve (c): apparent resistivity curve at Ndadop 


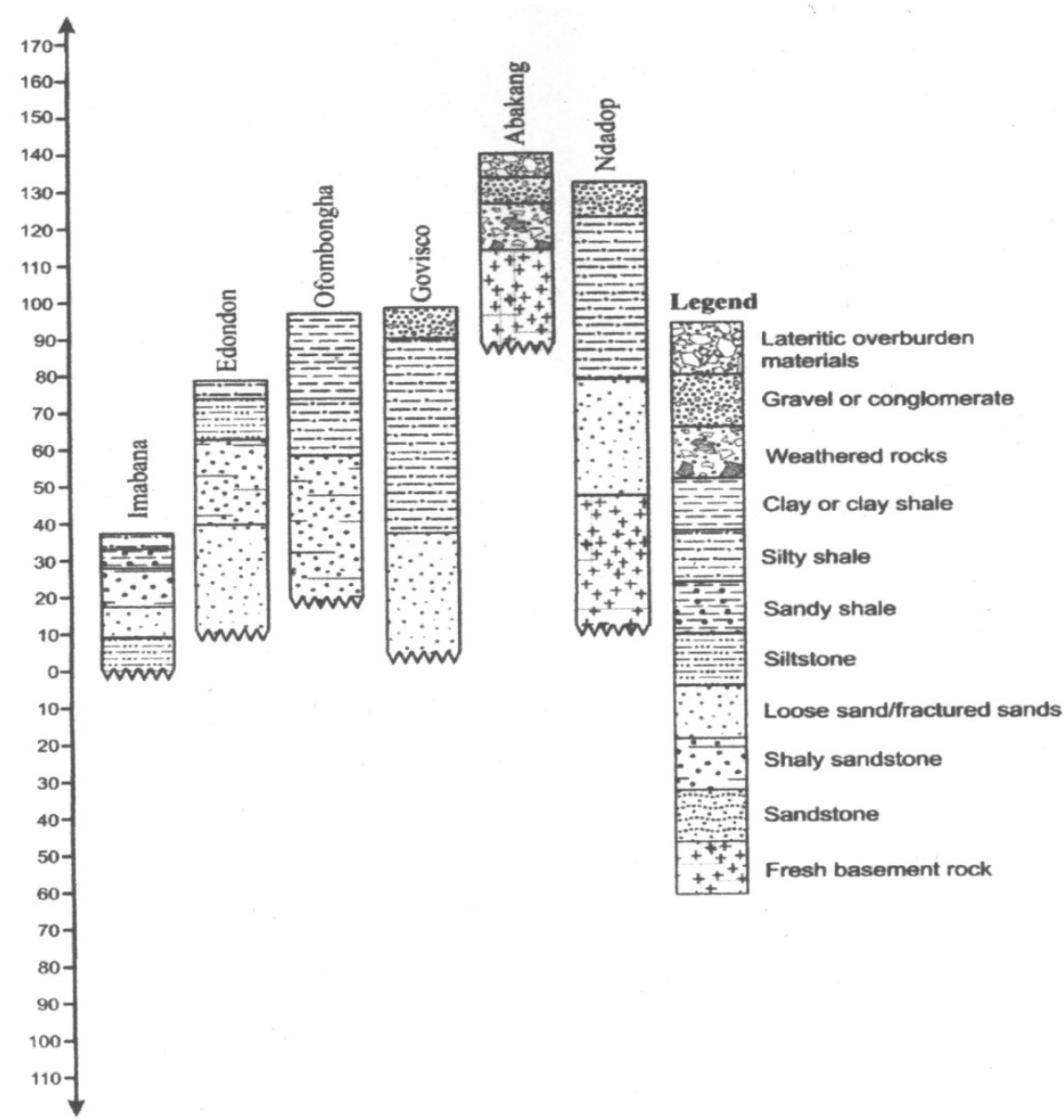

Figure 5. Lithostratigraphic logs from some of the boreholes in the study area

\section{Results}

The initial analysis of the VES data began with the computation of apparent resistivity, this was done by multiplying the apparent resistance by the pre-calculated geometrical factor using the Schlumberger array equation as expressed below:

$$
\rho_{a s}=\frac{\pi b^{2} R}{4 a}=\frac{\pi\left(\frac{A B}{2}\right)^{2}}{M N} \frac{\Delta V}{I}
$$

where $\rho_{a s}$ is the Schlumberger apparent resistivity, $A B$ is the current electrode distance, $M N$ is the potential electrode distance, $R$ is the apparent resistance, $\Delta V$ is the potential difference and $I$ is current. The calculated $\rho_{a s}$ of each sounding station was plotted against half of the current electrode spacing $A B / 2$ on a $\log -\log$ graph paper, VES curves were obtained and noisy segments were removed by manual smoothening (Bhattacharya, 1968; Chakravarthi et al., 2007).

The smoothening process involves either averaging of the observed electrical resistivity data at crossover points or out rightly deleting one of the data sets at crossover points and other outliers that fall significantly outside the dominant trend of the curve. Any discontinuity observed in the smoothened curve was attributed to vertical variation of electrical resistivity with depth. The smoothened curves were quantitatively interpreted in terms of true resistivity and thickness by a conventional manual curve matching procedure using master curves and auxiliary charts (Orellana \& Moony, 1966; Akpan et al., 2013).

Computer software Resist was used to model the results to improve on the manually interpreted results (Vender Velpen, 1988; Zohdy et al., 1980; Loke, 2001). The layer parameters (apparent resistivity, layer thickness and depth) realized initially from the manual interpretation stage were used as inputs into the computer modeling software. The software uses the parameters to generate data for the estimated model and compare the computed 
data with the measured data. This processing routine was repeated until the root mean square error resulting from the iteration process that produced the modeled data drops below $5 \%$.

The curves types generated from the modeling process are typically KH, HKH, HK, K, KHKH, KQ, KQH, KHH, AKQ, KAKH, Q, QQ, QQQ, AAK, AAKH, QH, HKQ, KQQ, QQH, and KKH types. These curves have 2-6 interpretable geo-electric layers. Typical resistivity curves that were made are shown in Figure 4(a-c). The KH, HKH and HK curve types dominated the curves with prevailing frequencies of $23.7 \%, 16.96 \%$ and $11.86 \%$. Evaluation of the reflection coefficient and resistivity contrast revealed that VES stations 6, 12, 26, 29, 36, 37, 45, 46, 47 and 60 have reflection coefficients and resistivity contrasts that are not less than 0.9 and 19 , respectively.

Results of the evaluated geoelectric parameters show that the sounding stations at Ogurude-Eda Road revealed two layers. At Ijutum-Eja Road, Adun Beach, Ofonbogha and Okimbongha three layers were revealed, while at Nyima, Owakande 2, Edondon, Ekporkpa, Okuni, Okuni-Okoroba Road, Abijang, Okuni-Ikom Road, Grass Field, Keteme-Boarder Road, Ajassor junction, Ejago-Kura, Agbokim Water Fall, Adijikpong, Bendeghe Ekim, Otere Ikom, Biajua, Danare, Abu Ogbangante, Mile 3 - Nsele, Govisco, Ntamantet, Bafin Etimtim and Ogep Osokom four layers were indicated. Five layers were indicated at Ugep-Ijiman, Iyamoyong/Iyametet Road, Egbezium, St. Thomas P/S Ugep, Lokpoi, Assigha, Oyadama,Itamtet Imabana, Ogurude, Ohanne-Eda, Ofio-Oji, Iyamoyong, Iyamitet, Mbetim Efraya, Last Motor, Ajassor, Etomi, Abia-Bendeghe Road, Ekigatia, Orimekpang, Bashua, Kayang, Abakang, Alok, Bansan Osokom, Obubra Bansam, Kakwagom, Boje and Edondon. The rest of the sounding points gave six layers.

\section{Discussion}

\subsection{Geoelectric Sections}

Analysis of the apparent resistivity curves (some of which are presented in Figure 4), reveals 2-6 layers that are characterized by low to moderately high resistivity values. The first layer which is exposed to the surface is characterized by electrical resistivity values that are generally less than $500 \Omega \mathrm{m}$ (that is $\rho_{1}<500 \Omega \mathrm{m}$ ), with a thickness that rarely exceeded $1.1 \mathrm{~m}$. In some locations where thickness of $5 \mathrm{~m}$ was observed, the rock is usually saturated with water and the yield can sustain hand dug wells, especially during the rainy season. Higher electrical resistivity values were observed in location where poorly cemented high grain size materials like gravels pebbles, coarse sands, breccias and other detrital materials dominate the litho-strata. Materials with low electrical resistivity values are prevalent in locations where surface outcrops of clayey and argillaceous materials were observed (Akpan et al., 2013). The top soil across the profile consists of decomposed organic materials and lateritic materials with silty clay intercalations.

The second geoelectrical layer is dominated by clay/shale with thickness of $2.6-10.2 \mathrm{~m}$ and resistivity of $90-$ $1,547 \Omega \mathrm{m}$. However, beneath Adun beach and Imabana, the least values of resistivity was recorded between $73-$ $90 \Omega \mathrm{m}$, thus particular section of the layer was delineated as shale. The shales are thick in some locations and the observed high and thick shale content of this layer suggests that primary porosity will be very low and consequently, water transmission and storage will be very poor (Odoh, 2010).

The electrical resistivity values of the third layer varied between $164-746 \Omega \mathrm{m}$, with thickness of $5.8-38 \mathrm{~m}$. These variations capture the variability of the lithology. Resistivity values of less than $30 \Omega \mathrm{m}$ in this layer were inferred to be responses from wet clays, while electrical resistivity values of over $500 \Omega \mathrm{m}$ were attributed to sandy/sandstone materials. These observeations show good correlation with lithology logs from nearby boreholes where sandy materials dominate the subsurface composition in this layer. The sands are usually saturated with water and form the dominant layer where groundwater is usually extracted from (Edet et al., 2011; Akpan et al., 2013).

There was no access made into the fourth layer in some locations like Ofombongha, Adun Beach and Imabana, whereas in locations like Ntamante, the electrical resistivity values where quite high $\left(\rho_{4}>8000 \Omega \mathrm{m}\right)$ which is indicative of wet basement rocks.

The fifth layer was touched at Abakang and Alok Nsadop, the electrical resistivity values ranges from $60-8342$ $\Omega \mathrm{m}$ and thickness between $40 \mathrm{~m}$ to $>110 \mathrm{~m}$, the resistivity

values around Alok and Nsadop presents a picture of a basement sedimentary contact, this contact is characterized by fractured basement and has the potential for water as indicated by the values of $<10^{4} \Omega \mathrm{m}$ which is the resistivity values for wet basement rocks (granite) (Loke \& Dahlin, 1997). 


\subsection{Aquifers}

Three geoelectrical sections were prepared for the study area (Figure 6), Figure 6(a) is a geoelectrical section trending Northwest - Southeast and shows the existence of thick aquifer units in the third layer with resistivity of $164-746 \Omega \mathrm{m}$ and thickness of $5.8-38 \mathrm{~m}$ and lies within a depth of $30-70 \mathrm{~m}$ beneath the surface. Apart from the third layer, the fifth layer also constitutes one of the aquiferous units in some location. Figure $6(\mathrm{~b})$ is a geoelectric section trending East - West, it shows the third layer as the aquiferous unit with resistivity between $121-291 \Omega \mathrm{m}$ and thickness of $5.1-154.0 \mathrm{~m}$, the resistivity range of these aquifer units suggests that the layer is dominated with sandy materials, the third layer in this geosection is highly variable and thins out greatly in some locations like Imabana $(3.3 \mathrm{~m})$ and Ababene $(3.6 \mathrm{~m})$, the thinning out of this lithostrata around Ababene and Imabana axis of the psuedosection results in a poor groundwater potential in this part of the profile.

The Northwest-Southeast geosection is shown in Figure 6(c), the third layer constitute the aquifer unit, with resistivity range of 74-257 $\Omega \mathrm{m}$ and thickness of 4.8-39.8 $\mathrm{m}$. The aquifer exists at a depth range of $27-75 \mathrm{~m}$, which can easily be tapped by both private and cooperate developers.

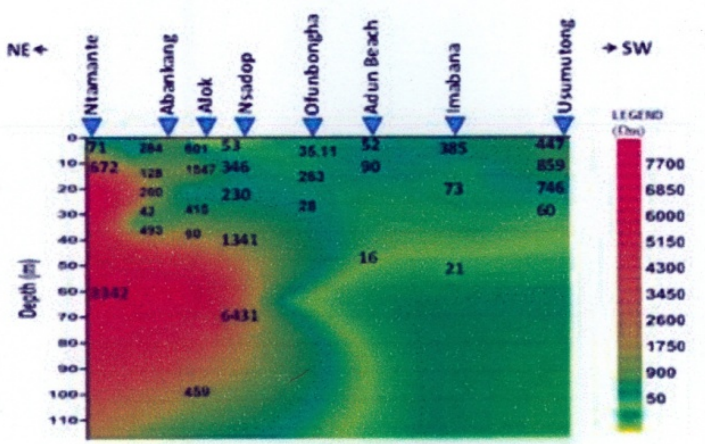

(a)

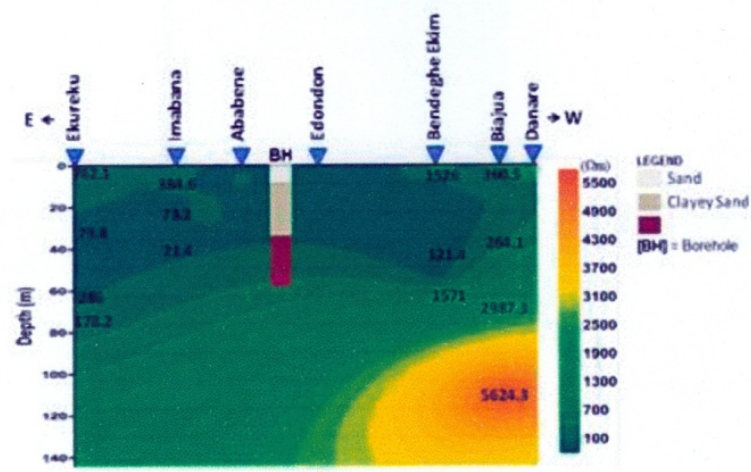

(b)

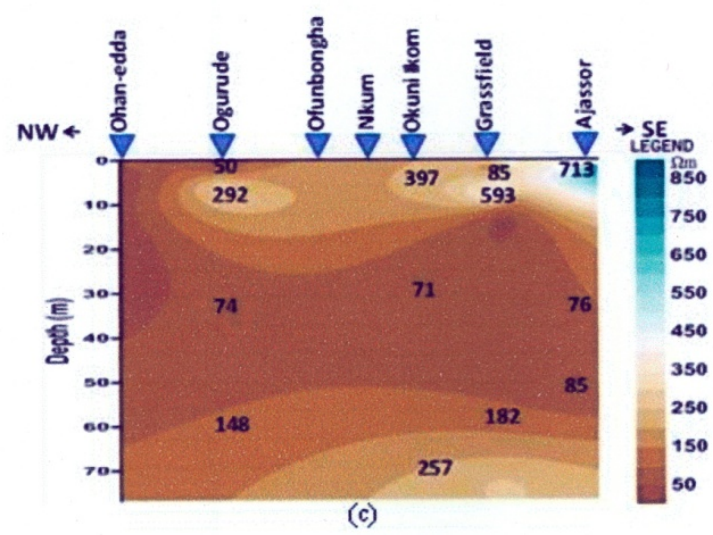

Figure 6. Model Geoelectric Psuedosections of the study area. Model (a): Northwest - Southwest Pseudosection; model (b): East-West Geoelectric Pseudosection; and model (c): Northwest - Southeast Pseudosection 


\section{Conclusion}

It is deduced from the evaluation of the reflection coefficient and resistivity contrast revealed that VES stations 6, 12, 26, 29, 36, 37, 45, 46, 47 and 60 (which were located at Iyamoyong/Iyametet Road, Onyadama, Iyamoyong, Onyenokpon, Grass Field, Keteme-boarder Road, Ekigatia, Agbokim Water Fall, Adijikpong and Edor, respectively) are areas with high density water fractures because their reflection coefficients and resistivity contrasts were not less than 0.9 and 19, respectively. There is a variation in the depth to water table in the study area. The trend of the variation is from Northeast to Southwest, with range of values of 10-50 m and 60-110 m, respectively.

As mentioned earlier, a maximum of six geoelectric layers were obtained from the interpretation of the sounding data. The electrical resistivity of the first layer was between $100 \Omega \mathrm{m}$ and $2,115 \Omega \mathrm{m}$ which was indicative of clay/shale/sandy silt. The second layer resistivity was between $9.4 \Omega \mathrm{m}$ and 4,317.0 $\Omega \mathrm{m}$. This was inferred to be shalestone/shale. It was underlain by the third layer which had a resistivity range of $100-5422 \Omega \mathrm{m}$, inferred as sandstone. The materials of this layer is indicative of an aquifer. The fourth layer had resistivity values that range from $10.6 \Omega \mathrm{m}$ to $6,415.0 \Omega \mathrm{m}$. The fifth layer resistivity values were between 8.4 and 3,511.2 $\Omega \mathrm{m}$, while the last layer had resistivity values between $10.0 \Omega \mathrm{m}$ and $6,103.0 \Omega \mathrm{m}$.

The productive shallow aquifer terrains in the study area according to borehole lithology log are made up of fine sands and sandstones with resistivity ranges of 100-500 $\Omega \mathrm{m}$ and depth of $60 \mathrm{~m}$. This shallow terrains are horizontally aligned in the study area. The deep aquifer terrains which consist of coarse grained sands and fractured basement, had resistivity range of 1000-2,500 $\Omega \mathrm{m}$ and a depth from surface to bottom of about $150 \mathrm{~m}$. The area has been identified to have confined aquifer terrain due to the confining clay layer which is of large vertical extent in the adjacent layers that enclosed the aquifer.

\section{References}

Akpan, A. E., Ugbaja, A. N., \& George, N. J. (2013). Integrated Geophysical, Geochemical and hydrogeological investigation of shallow ground water resources in parts of the Ikom-Mamfe Embayment and the adjourning in Cross River State, Nigeria. Environ. Earth Sci. http://dx.doi.org/10/1007/s12665-013-2232-3

Ayolabi, E. A. (2004). Seismic refraction survey of University of Lagos, Nigeria and its implication. Journal of Applied Sciences, 7(3), 4319-4327.

Ayolabi, E. A., Adeoti, L., Oshinlaja, N. A., Adeosun, I. O., \& Idowu, O. I. (2009). Seismic refraction and resistivity studies of part of Igbogbo township, south-west Nigeria. Journal of Scientific Research and Development, 11, 42-61.

Benkhelil, M. G., Ponsard, J. F., \& Saugy, L. (1975). The Bornu-Benue Trough, The Niger Delta and its offshore Tectono-sedimentary reconstruction during the cretaceous and Tertiary from geophysical and geology. In C. A. Kogbe (Ed) Geology of Nigeria (pp. 277-309). Elizabethan Press, Lagos.

Bernard, J. (2003). Short notes on depth of investigation of electrical methods. Retrieved from www.iris-instruments.com

Bhathacharya, P. K., \& Patra, H. P. (1968). Direct current geoelectric sounding: principles and interpretation. Elsevier Science Publishing Co. Inc., Amsterdam.

Burton, A. N. (1976). The use of geophysical methods in Engineering Geology, Part 1: Seismic Techniques. Ground Engineering.

Chakravarthi, V. Shankar, G. B. K., Muralikharan, D., Harinarayana, T., \& Sundarajan, N. (2007). An integrated geophysical approach to imaging subbasal Sedimentary Basin: case study of Jam River Basin, India. Geophysics, 72(6), B141-B147. http://dx.doi.org/10.1190/12777004

Cross River Basin Development Authority (CRBDA). (1982). Inventory of Natural Site conditions, soils slopes, hydrology, landuse and vegetation throughout the area of operation of the authority. Technical report 4.

Drake, C. L. (1962). Geophysics and Engineering. Geophysics, 27, 193-197.

Early, K. R., \& Dyer, K. R. (1964). The use of resistivity survey in foundation site underlain by Karst dolomite. Geotechnique, 14, 341-348.

Edet, A. E., Nganje, T. N., Ukpong, A. J., \& Ekwere, A. S. (2011). Groundwater chemistry and quality of Nigeria: A Status Review. African Journal of Environmental Science and Technology, 5(13), 1152-1169, http://dx.doi.org/10.5897/AJESTX11.011 
Eseme, E., Agyingi, C. M., \& Foba-Tendo, J. (2002). Geochemistry and genesis of brime emanation from cretaceous strata of the Mamfe Basin, Cameroun, J. Afri. Earth Sc., 35, 467-4776 http://dx.doi.org/10/1016/50899-55362(2)00171-9.

Keary, P., \& Brooks, M. (1984). An introduction to geophysical exploration (pp. 198-217). Blackwell Scientific publication, Oxford.

Kurtenacker, K. S. (1934). Some practical application of resistivity measurement to highway problem. Transaction of American Institute of Mining and Metallurgical Engineers, 110, 193-205.

Loke, M. H., \& Dahlin, T. (1997). A combined Gauss-Newton and Quasi-Newton inversion method for the interpretation of apparent resistivity pseudosections. Procedures of $3^{\text {rd }}$ meeting of the European Association of Environmental and Engineering Geophysics. 8-11 September, 1997, Aarhus, Denmark, 139-142.

Loke, M. H. (2001). RES ID version 1.0 for Windows 95/98/ME/2000/NT, I-D Resistivity. IP and SP inversion and forward modeling for Wenner and Shlumberger arrays.

Nigeria Geological Survey Agency (NGSA). (2006). Geological and mineral resources map of Cross River State, Nigeria.

Nunn, K. R. (1979). Geophysical survey at two landfill sites in the west midlands. Symposium on the engineering behaviour of industrial and urban hill.

Odigi, M. I., \& Amajor, L. C. (2009). Geochemical characterization of cretaceous sandstones from the southern Benue Trough, Nigeria. Chin. J. GEochem., 28, 044-054. http://dx.doi.org/10.1007/s11631-009-00447

Odoh, B. I. (2010). Surface-outcrop characterization for fracture flow of groundwater: case study of ABakaliki Basin, Ebonyi State, Nigeria. Int. Arch. Appl. Sci. Technol., 1(1), 45-53.

Offodile, M. E. (1975). A review of the geology and cretaceous of the Benue valley (pp. 375-376). In C. A. Kogbe (Ed), Geology of Nigeria. Elizabethan Press Lagos.

Olorunfemi, M. O., \& Meshida, E. A. (1987). Engineering Geophysics and its application in Engineering site investigations (Case study from Ile-Ife area). The Nigerian Engineer., 22, 57-66.

Orellana, E., \& Mooney, H. (1966). Master tables and curves for vertical electrical soundings over layered structures of Madrid. Interciencia: India.

Petters, S. W. (1989). A regional hydrogeological study of rural water supply options for planning and implementation of phase II rural water programme in Cross River State. Unpublished Technical report submitted to DIFFRI, Cross River State.

Petters, S. W., Okereke, C. S., \& Nwajide, C. S. (1987). Geology of the Mamfe Rift, south eastern Nigeria. In G. Mathesis, \& J. Shandemerer (Eds), Current research in African Earth Sciences (pp. 299-302). Balkema Rotterda.

Roy, A., \& Apparao, A. (1971). Depth of investigation in direct current methods. Geophysics, 36(5), 943-959.

Vender Velpa, B. P. A. (1988). A computer processing package for DC Resistivity interpretation for IBM compatibles. ITC Journal 4, The Netherlands.

Zohdy, A. A. R., Eaton, G. P., \& Mabey, D. R. (1980). Application of surface geophysics to groundwater investigations. U.S. Government printing office: Washington D.C.

\section{Copyrights}

Copyright for this article is retained by the author(s), with first publication rights granted to the journal.

This is an open-access article distributed under the terms and conditions of the Creative Commons Attribution license (http://creativecommons.org/licenses/by/3.0/). 